\title{
Anting behavior by the White-bearded Manakin (Manacus manacus, Pipridae): an example of functional interaction in a frugivorous lekking bird
}

\author{
César Cestari ${ }^{1,2}$ \\ ${ }^{1}$ Departamento de Zoologia, Programa de Pós-graduação em Zoologia, Universidade Estadual Paulista \\ “Júlio de Mesquita Filho" - UNESP, Campus de Rio Claro, CEP 13506-900, Rio Claro, SP, Brasil \\ ${ }^{2}$ Corresponding author: César Cestari,e-mail: cesar_cestari@yahoo.com.br
}

CESTARI, C. Anting behavior by the White-bearded Manakin (Manacus manacus, Pipridae): an example of functional interaction in a frugivorous lekking bird. Biota Neotrop. 10(4): http://www.biotaneotropica.org. br/v10n4/en/abstract?short-communication+bn02110042010.

\begin{abstract}
Behavioral studies of birds have reported several functions for active anting. Maintenance of plumage and prevention from ectoparasites are some examples. In this context, anting by males may be of particular importance in a classical lek mating system, where male-male competition is common and individuals with higher fitness may be more successful at attracting of females. In the present note, I describe the anting behavior of White-bearded Manakin (Manacus manacus) and I relate it to lek breeding and feeding (frugivory) habits of the species. Males used up to seven Solenopsis sp. ants. They rubbed each small ant from 4 to 31 times on undertail feathers until the ants were degraded; ants were not eaten. Males then searched for a new ant in the court. Seeds discarded by males on their individual display courts attract herbivorous ants that are used for anting as a way to maintain feathers and fitness. I hypothesize that anting in White-bearded Manakin may increase the probability of males to attract females to their display courts.
\end{abstract}

Keywords: ants, lek, male-male competition, maintenance of plumage, restinga forest, seeds.

CESTARI, C. Comportamento de formicar-se da rendeira (Manacus manacus, Pipridae): um exemplo de interação funcional em um pássaro frugívoro com comportamento de lek. Biota Neotrop. 10(4): http://www. biotaneotropica.org.br/v10n4/pt/abstract?short-communication+bn02110042010.

Resumo: Estudos sobre comportamento de aves têm reportado várias funções para o ato de formicar-se. A manutenção de plumagem e prevenção de ectoparasitas são alguns exemplos. Nesse contexto, o comportamento de formicar-se em machos alcança importância maior em um sistema de lek clássico, onde a competição sexual entre machos é comum e indivíduos com boa condição física podem ter mais sucesso na atração de fêmeas. Na presente nota, eu descrevo o comportamento de formicar-se da rendeira (Manacus manacus) relacionando-o com os hábitos frugívoro e reprodução em lek da espécie. Os machos utilizaram até sete formigas Solenopsis sp. durante o comportamento de formicar-se. Eles esfregaram cada formiga entre 4 a 31 vezes em suas penas caudais inferiores até a completa degradação das formigas, sem ingerí-las. Posteriormente, os machos procuraram por uma nova formiga em suas arenas. As sementes descartadas por machos em suas arenas de exibição atraem formigas herbívoras que são utilizadas para formicarem-se como uma forma de manutenção de penas e de boa condição física. Provavelmente, o comportamento de formicar-se colabora para o aumento da habilidade de machos na atração de fêmeas para suas arenas de exibição.

Palavras-chave: formigas, lek, competição entre machos, manutenção de plumagem, floresta de restinga, sementes. 


\section{Introduction}

Active anting is defined as a bird holding an ant and rubbing it in parts of the body, discharging toxic and distasteful substances before ingesting or discarding it (Groskin 1950). Formic acid is one of the substances found in some groups of ants. It acts smoothing skin irritation and as an insecticide, bactericidal, and fungicide on bird feathers (Groskin 1950, Simmons 1957, 1959, Hart 1997, Clayton 1999). Thus, plumage maintenance and prevention of ectoparasites are some of the functions attributed to anting behavior (Groskin 1950, Simmons 1959, 1966, Judson \& Bennett 1992). For birds that also eat the ant, removal of toxic or distasteful substances during rubbing and before the ingestion is also considered a protective behavior (Potter 1970, Judson \& Bennett 1992). Several passerine birds are recorded anting in the Neotropical region (Willis 1972, Sick 1997, Sazima 2009).

Manakins (Pipridae) have the lek behavior and frugivory as predominant studied features (Snow 2004). The term lek refers to a variety of courtship behaviors that concentrate more than one male in a display area with the main purpose to attract and stimulate the females to mate (Sick 1967, Höglund \& Alatalo 1995). In the manakins, sexual competition by single or grouped males are well evident, as they spend great part of the day in fixed courtship places to attract females. In these occasions, brief intervals are dedicated to maintenance of plumage and feeding activities on fruits, or occasionally on insects (Sick 1967, Snow 2004). As a consequence, males frequently maintain a showy appearance in display sessions and regurgitate or defecate a lot of seeds in and around their fixed display courts (Snow 2004). In the present note, I describe the anting behavior of the White-bearded Manakin (Manacus manacus, Linnaeus 1766) and link it with the cycle of biotic and functional interactions of this species, including frugivory, self-care and lek behavior following this presumable sequence of events: (1) the accumulation of seeds defecated or regurgitated by competing males in and around display courts may (2) attracts herbivore ants that (3) M. manacus males use anting as a way to (4) maintain their feathers and individual fitness during intra-specific competition on lek areas.

\section{Material and Methods}

Manacus manacus is a small forest bird with range of weight from 12 to $16 \mathrm{~g}$. Males are black and white whereas females are dull green (Snow 2004). Observations of anting behavior of M. manacus were conducted in the lowland restinga forests at Itanhaém municipality (24 $14^{\prime} 11.9^{\prime \prime} \mathrm{S}$ and $\left.46^{\circ} 55^{\prime} 32.81^{\prime \prime} \mathrm{W}\right)$, and Juréia Itatins Ecological Station (Iguape municipality, $24^{\circ} 28^{\prime} 07.4^{\prime \prime} \mathrm{S}$ and $47^{\circ} 07^{\prime} 13.17^{\prime \prime} \mathrm{W}$ ), São Paulo State in Southeastern Brazil. These observations were part of a year-long study of this species' behavior in a lek system. Both areas are still covered with great part of restinga vegetation, an Atlantic forest ecosystem threatened by urban expansion (Sampaio 2005). Typical plants of the region are Myrtaceae, Leguminosae, Rubiaceae, Melastomataceae, Lauraceae and Annonaceae (Mamede et al. 2004). Climate is subtropical and humid. Mean annual rainfall is $2278 \mathrm{~mm}$ with the rainy season occurring from October to April, and the dry season from May to September. Mean annual temperature is $21.4^{\circ} \mathrm{C}$, with maximum mean temperature of $25.8^{\circ} \mathrm{C}$ and minimum mean temperature of $19.0^{\circ} \mathrm{C}$ (Tarifa 2004).

The studied areas of nearly $400 \mathrm{~m}^{2}$ concentrate 8 to 10 display courts where resident males peak their exhibitions between July to January (C. C., pers. obs.). The display court is characterized as an oval arena delimited by two or more saplings on the ground and varies from 0.15 to $0.9 \mathrm{~m}$ diameter. It is actively cleared from litter by a lekking resident male (Darnton 1958, Snow 1962, Lill 1974a, Olson \& McDowell 1983, Shorey 2002). During the breeding season, males may spend $90 \%$ of their time on display grounds (Snow 1962). They use this amount of time in displays maneuvers, territory defense against co-specific male's invaders, foraging on fruits or occasionally insects, preening and anting.

"Ad libitum" observations were conducted in the present study (Martin \& Bateson 1986). A distance of nearly five meters from a male's courts was kept and appropriated camouflaged clothes were adopted to minimize interference on the bird's behavior. Digital photographs were used to record the anting behavior and as parameter for descriptive analyses.

\section{Results}

On 17 and 19 December 2009, and 13 January 2010, I recorded anting behavior by lekking Manacus manacus males. Alternated observations of display courts of six different lekking males were conducted three days per month between 6:00 to 17:00 hours. From these, three males displayed anting behavior in periods of 16,21 , and 44 minutes, respectively. As the anting events were similar for the three males, I chose the longest one (13 January 2010) to describe here.

The anting activity lasted 44 minutes. It started at 7:45 hours and ended at 8:29 hours including the period of searching for ants. My first impression was that the male was preening, but detailed observation revealed that the male was actively rubbing ants on its body and searching for more ants within its court. This male used a total of seven Solenopsis sp. ants during its anting activity. For a few seconds, the male rubbed each ant from 4 to 31 times on its undertail feathers until the ants were degraded. After this, the male searched for a new ant within the display court (Figure $1 \mathrm{a}-\mathrm{c}$ ). Both the ground and the saplings of the display court were used for anting.
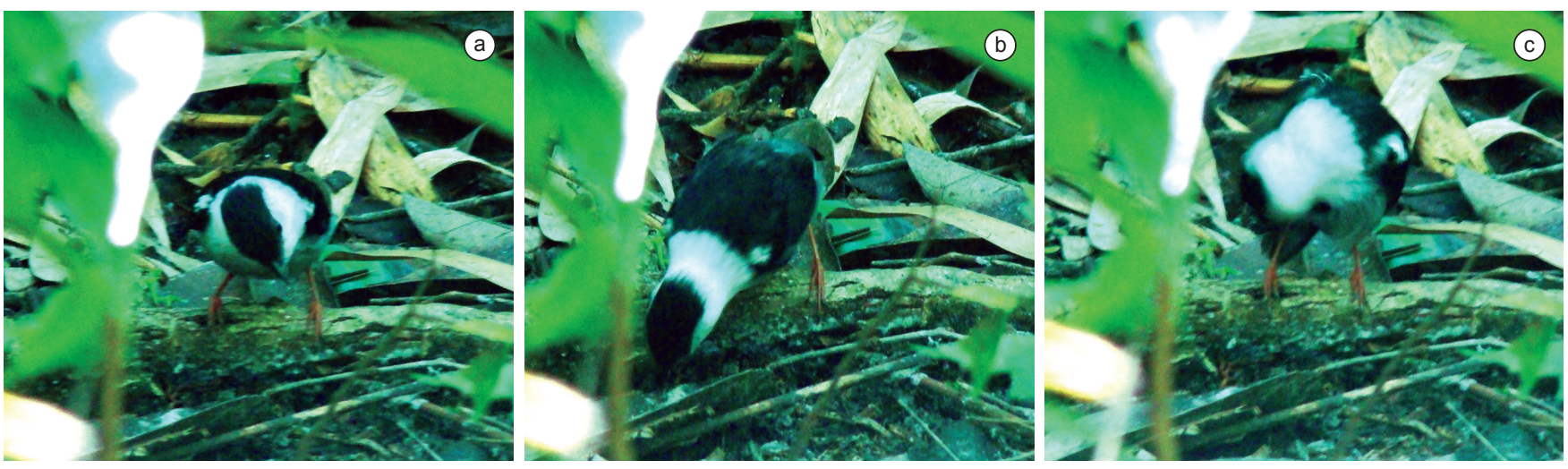

Figure.1. Anting behavior of a White-bearded Manakin (Manacus manacus) male on the ground. a) Searching for ants; b) capturing an ant; c) rubbing the ant on its undertail coverts.

Figura 1. Comportamento de formicar-se de um macho de rendeira (Manacus manacus) no chão. a) Procurando formigas; b) capturando uma formiga; c) esfregando uma formiga nas penas inferiores de sua cauda. 


\section{Discussion}

Anting behavior was probably used for maintenance of plumage by males of $M$. manacus as it is suggested for several passerines species (Simmons 1959). Intra-specific competition between males becomes evident in a lek system and anting probably contributed to a male's fitness influencing the attraction of females to individual courts. Other not exclusive biological features may influence the mating system in M. manacus, such as larger male size, higher frequency of aggressive displays and territory defense, larger territory size, and low distance of the court from the lek centre (Snow 1962, Lill 1974a, Olson \& McDowell 1983, Shorey 2002).

Courtship displays in lekking birds may be energetically costly for males (Vehrencamp et al. 1989, Höglund \& Alatalo 1995). Regarding all factors that may drive the attractiveness of males, individuals that have better external and physical conditions will compete more efficiently for females (Kirkpatrick \& Ryan 1991). Ectoparasites signalize the current health condition of birds, and affect negatively the fitness of males by increasing the cost of antiparasite effects in their immune system, causing loss of blood, infections, and diseases (Price 1980, de Lope et al. 1993, Doucet $\&$ Montgomerie 2003). Additionally, females are able to enhance the viability of their offspring by choosing males with better physical conditions as an indicator of relative resistance to parasites (Hamilton \& Zuk 1982).

Studies on parasite loads in lekking birds seem to indicate that parasites do have adverse effects on mating success (Höglund \& Alatalo 1995). Thus, prevention of ectoparasites and other harmful organisms such as fungi and bacteria on feathers are advantageous for males by influencing their showy appearance and improving lek performance. Although the anting behavior has not been previously reported to manakins, it may be advantageous for individual males even if it may be a rare situation as appears to be in the present study.

Regurgitated and defecated seeds by manakin males in and around the display courts may retain part of fruit-nutrients that attract herbivorous insects, thus becoming important for anting behavior in M. manacus. Seven ornitochoric seeds and 18 Solenopsis sp. were found in the male court during the observation. According to Passos and Oliveira (2003), small Myrmicinae ants such as Solenopsis sp. are common in the lowland forest of restinga, and many nestmates are recruited to diaspores, consuming the pulp and aril locally.

Behavioral studies of $M$. manacus were available for at least since 50 years (see Darnton 1958, Snow 1962, Lill 1974a, b, Olson \& McDowell 1983, Shorey 2002) and revealed a complexity of biological features that may influence the species' mating system. The cycle of functional interactions in which anting behavior of M. manacus occurs is another fascinating feature of this species' natural history. In spite the rarity of anting, experimental studies might demonstrate that males that use anting do in fact enhance their long-term fitness relative to males that do not use anting.

\section{Acknowledgements}

I’m indebted to Ílson L. Prado, Rubens R. do Prado, Sr. Plínio and all the staff of Juréia Ecological Station that facilitate my logistics and share knowledge about natural history of the region. I thank two anonymous reviewers for considerably improving this manuscript, Marco A. Pizo for guidance in my thesis, and especially Cristina S. Gonçalves for help in field observations and love support. I also acknowledge the finantial support from FAPESP, and a research grant from the Brazilian Research Council (CNPq).

\section{References}

CLAYTON, D.H. 1999. Feather-busting bacteria. Auk 116(2):302-304.

DARNTON, I. 1958. The display of the manakin Manacus manacus. Ibis 100(1):52-58.

DE LOPE, F., GONZALEZ, G., PEREZ, J.J., MAILER, A.P. 1993. Increased detrimental effects of ectoparasites on their bird hosts during adverse environmental conditions. Oecologia 95(2):234-240.

DOUCET, S.M. \& MONTGOMERIE, R. 2003. Structural plumage colour and parasites in satin bowerbirds Ptilonorhynchus violaceus: implications for sexual selection. J. Avian Biol. 34:237-242.

GROSKIN, H. 1950. Observations on "anting" by birds. Auk 67(2):201209.

HAMILTON, W.D. \& ZUK, M. 1982. Heritable true fitness and bright birds: a role for parasites? Science. 218:384-387.

HART, B.L. 1997. Behavioral defence. In Host-parasite evolution: general principles and avian models (D.H. Clayton \& J. Moore, ed.). Oxford University Press, Oxford, p.59-77.

HÖGLUND, J. \& ALATALO, R.V. 1995. Leks. Princeton University Press, New Jersey.

JUDSON, O.P. \& BENNETT, A.T.D. 1992. "Anting" as food preparation: formic acid is worse on an empty stomach. Behav. Ecol. Sociobiol. 31(6):437-439.

KIRKPATRICK, M. \& RYAN, M.J. 1991. The evolution of mating preference and the paradox of the lek. Nature 350(6313):33-38.

LILL, A. 1974a. Sexual behavior in the lek-forming White-bearded Manakin (Manacus manacus trinitatis Hartert). Z. Tierpsychology 36:1-36

LILL, A. 1974b. Social organization and space utilization in the lek-forming White-bearded Manakin (Manacus manacus trinitatis Hartert). Z. Tierpsychology 36:513-530.

MAMEDE, M.C.H., CORDEIRO, I., ROSSI, L., MELO, M.M.R.F. \& OLIVEIRA, R.J. 2004. Mata Atlântica. In Estação Ecológica JuréiaItatins: ambiente físico, flora e fauna (O.A.V. Marques \& W. Duleba, ed.). Holos, Ribeirão Preto, p.115-132.

MARTIN, P. \& BATESON, P. 1986. Measuring behaviour, an introductory guide. Cambridge University Press, Cambridge.

OLSON, D.H. \& McDOWELL, M.K. 1983. A comparison of Whte-bearded Manakin (Manacus manacus) populations and lek systems in Suriname and Trinidad. Auk 100(3):739-742.

PASSOS, L. \& OLIVEIRA, P.S. 2003. Interactions between ants, fruits and seeds in a restinga forest in south-eastern Brazil. J. Trop. Ecol. 19(3):261-270

POTTER, E.F. 1970. Anting in wild birds, its frequency and probable purpose. Auk 87(4):692-713.

PRICE, P.W. 1980. Evolutionary biology of parasites. Princeton University Press, Princeton.

SAMPAIO, D. 2005. Restinga. In Árvores da restinga: guia de identificação (D. Sampaio, V.C. Souza, A.A. Oliveira, J.E. Paula-Souza \& R.R. Rodrigues, ed.). Neotrópica, São Paulo, p.25-30.

SAZIMA, I. 2009. Anting behavior with millipedes by the dendrocolaptid bird Xiphocolaptes albicollis in Southeastern Brazil. Biota Neotrop. 9(1): http://www.biotaneotropica.org.br/v9n1/en/abstract?shortcommunication+bn00609012009. (último acesso em 22/08/10).

SHOREY, L. 2002. Mating success on White-bearded Manakin (Manacus manacus) leks: male characteristics and relatedness. Behav. Ecol. Sociobiol. 52(6):451-457.

SICK, H. 1967. Courtship behavior in the manakins (Pipridae): a review. Living Bird. 6:5-22.

SICK, H. 1997. Ornitologia Brasileira. Nova Fronteira, Rio de Janeiro.

SIMMONS, K.E.L. 1957. A review of the anting-behavior of passerine birds. Brit. Birds. 50:401-424.

SIMMONS, K.E.L. 1959. Anting movements and their relationship to certain other behavior patterns. Ibis 101(3):368-373. 
Cestari, C.

SIMMONS, K.E.L. 1966. Anting and the problem of self-stimulation. J. Zool. 149(2):145-162.

SNOW, D. 1962. A field study of the Black and White Manakin, Manacus manacus, in Trinidad. Zoologica 47(8):65-103.

SNOW, D. 2004. Family Pipridae (manakins). In Handbook of the birds of the world (J. del Hoyo, A. Elliott \& J. Sargatal, ed.). Lynx Editions, Barcelona, v.9, p.110-169.
TARIFA, J.R. 2004. Unidades climáticas dos maciços litorâneos da JuréiaItatins. In Estação ecológica Juréia-Itatins: ambiente físico, flora e fauna (O.A.V. Marques \& W. Duleba, ed.). Holos, Ribeirão Preto, p.42-50.

VEHRENCAMP, S.L., BRADBURY, J. \& GIBSON, R. 1989. The energetic cost of display in male sage grouse. Anim. Behav. 38(5):885-896.

WILLIS, E.O. 1972. The behavior of plain-brown woodcreepers, Dendrocincla fuliginosa. Wilson Bull. 84(4):377-420. 